\title{
OPHTHALMOLOGY EMERGENCY ROOM AT THE UNIVERSITY OF SÃO PAULO GENERAL HOSPITAL: A TERTIARY HOSPITAL PROVIDING PRIMARY AND SECONDARY LEVEL CARE
}

\author{
Regina de Souza Carvalho, Newton Kara José
}

Carvalho RS, Kara José N. Ophthalmology emergency room at the University of São Paulo General Hospital: a tertiary hospital providing primary and secondary level care. Clinics. 2007;62(3):301-8.

OBJECTIVE: To assess the need for emergency care in a tertiary hospital, in the Ophthalmology Emergency Room of the University of the São Paulo Medical School General Hospital.

MATERIALS AND METHODS: A cross-sectional analytic study of the treatment complexity level was carried out in a readily available sample, $n=574$, of patients seen at the Ophthalmology Emergency Room of the University of São Paulo Medical School General Hospital, during a typical week.

RESULTS: Of the 574 treated patients, $69.0 \%$ of the cases were diagnosed as requiring a simple treatment for their problem. The most frequent diagnoses were related to ocular inflammation and infection (55.0\%), mainly including conjunctivitis (29.4\%) and eyelid inflammations (10.5\%). Next in frequency were ocular trauma (19.2\%), particularly foreign bodies on the cornea $(7.5 \%)$ and blunt trauma (5.2\%). Refractive errors (3.1\%) was the most prevalent diagnosis in the "other ocular modifications" category. CONCLUSION: Most of the cases (69.0\%) treated at the Ophthalmology Emergency Room of the University of São Paulo Medical School General Hospital could have been diagnosed and treated in primary or secondary care units. Also, the fact that return visits to check recovery are seen in the ER demonstrates the lack of referral services. The fact that patients come to a tertiary hospital with rather simple cases shows the poor structure of the Brazilian Public Healthcare System, which overloads the tertiary care facilities, where costs for human resources, materials, and other items are higher.

KEYWORDS: ER. Emergency. Ophthalmologic treatment. The Brazilian Public Healthcare System. Levels of care.

\section{INTRODUCTION}

Formal attempts to organize emergency care in Brazil are frequently repeated and aim at creating a network configuration modelled after the basic principles of the Brazilian Public Healthcare System (called SUS) as follows: universality of access, fairness, integrity, effective resolution of problems, hierarchical structure and humanization, as well as setting standards for professional training and

University of the São Paulo Medical School General Hospital. Ophthalmology Clinic, Sao Paulo University Medical School, Sao Paulo/SP, Brazil.

Email; regina-sc@uol.com.br

Received for publication on November 21, 2006.

Accepted for publication on February 14, 2007. practice of those who work in the area of emergency care.1

Since SUS was created, emergency care has always been concentrated in hospitals. The flow of hospital users is still mainly determined by their own choice of where to seek medical care, resulting in crowded emergency rooms and, consequently, low-quality assistance ${ }^{2}$, as might be expected.

The fact of the matter is that emergency assistance in most large cities has a profile similar to the Brazilian Public Healthcare System: long lines for appointments, exams, and surgeries; shortage of rooms available for hospitalization; and lack of appropriate human resources. Patients in emergency rooms are diversified but have in common their expectations of receiving adequate care, although little is done to shelter them or to screen them from risk. In addition, 
the patient who has been examined in the emergency room cannot obtain treatment follow-up in a primary or secondary care unit, having to return repeatedly to the Emergency Room (ER) for treatment. ${ }^{3}$

The Brazilian Ministry of Health seeks to correct this situation through a series of actions that imply a detailed reading of social needs in terms of healthcare, such as the organization of regional emergency assistance networks, involving all elements that integrate the public healthcare system, ie, the SUS. ${ }^{4,5}$

As stated in the basic assumptions of the Brazilian Public Healthcare System, the network should be deployed in such a way as to integrate services of growing complexity into 3 levels of care- primary, secondary, and tertiary ${ }^{-}$classified according to the degree of material technology incorporation and the capabilities of the institutions' graduate-level staffs, as follows:

- Primary care. Primary care units include the following: family health units; outpatient clinics; healthcare centers/ basic healthcare units, where people are provided with integral medical assistance, sometimes with scheduled appointments, from some basic specialists; they also offer dental assistance and other kinds of professional care; assistance must be permanent and given by general practitioners or specialists in these areas; 24hour emergency care may or may not be offered; "travel boat" units; and mobile land units for medical/dental care. $^{6}$

- Secondary care. Secondary care units are mixed units where typical activities of a healthcare center are carried out, including hospitalization in the areas of pediatrics, obstetrics, internal medicine, surgery, and emergency care. They comprise a higher level of technology incorporation and better qualified personnel; "polyclinics" or medical assistance centers, and emergency rooms (ER). ${ }^{7}$

- Tertiary care. Tertiary care units comprise some emergency rooms and hospitals that are focused mainly on medical assistance for hospitalization, working day and night and with various levels of technology incorporation, with permanently available medical and nursing staff. They may be classified according to size (small, medium, and large) and according to the offered level of technological resources (low, moderate, and high), although some of them work exclusively with more specialized assistance. ${ }^{7}$

Ideally, the Brazilian Public Healthcare System should be accessed by the users at the basic healthcare units (Basic Healthcare Units and Family Health Units-primary care), with patients being referred to other levels, as required, depending on personnel skills and technological re- sources to be applied in diagnosis and resolution of the patient's condition. ${ }^{2}$

According to Brazilian policy, the Basic Healthcare Units, the Family Healthcare Program, and the corresponding teams of Community Healthcare Support Agents, should be structured and trained to face urgent situations of minor complexity, in addition to providing immediate care or performing life-saving measures in the more severe cases. ${ }^{5}$

The specialized network (tertiary level) should be ready to assist patients requiring specific long-term follow-up, providing qualified support in acute episodes, and responding promptly when patients seen at the ER require investigation and/or follow-up. ${ }^{5}$

The University of São Paulo Medical School General Hospital is a tertiary care facility. In addition to its healthcare purposes, its objective is to provide students and interns with high-quality education. Both activities, together, set the stage for scientific research, which, indirectly, in turn, fosters education and improves assistance. ${ }^{8}$

The Emergency Room of the University of São Paulo Medical School General Hospital has become one of the largest ER services in the country as regards the number of patients received, but this has gradually led to a chronically deficient level of service, inadequate for this kind of setup. ${ }^{8}$

Given its complex specialization, services provided by the University of São Paulo General Hospital, material resources available, and the fact that it is a medical school hospital, it is unsuitable for providing care to patients with any medical condition without prior selection. Originally, medical care at this General Hospital was focused on highly complex cases that could not receive appropriate attention in primary care units. ${ }^{9}$

The Ophthalmology ER of University of São Paulo Medical School General Hospital receives a large number of patients, corresponding, on average, to $13.5 \%$ of all the patients seen by the entire ER. ${ }^{8}$ This high demand requires that the staff's attention and material resources (medication, equipment, and hospital beds) be shared by patients who really need the services provided by the hospital and those who could be treated in primary or secondary care units; the consequence is that the former receive lower quality services than they otherwise would. ${ }^{9}$

The objective of this study was to determine the need for tertiary care services among the patients seen at the Ophthalmology ER of University of São Paulo General Hospital.

\section{METHODS}

A cross-sectional analytical survey was carried out on 581 medical files of patients seen at the ER of the Gen- 
eral Hospital of São Paulo University Medical School during the week from 01-Apr-06 to 08-Apr-06 (considered to be a "typical" week in terms of the number of patients attended).

The study covered the period starting 6 am of the 1 st April 2006 and ending 6 am of the 8th April 2006, round the clock.

The survey included all the medical files of the patients seen at the ER of the Hospital during the study period who went through an ophthalmologic consultation. Patients with an admission register but who left the hospital before being seen by the ophtalmologist and therefore went without a diagnosis were excluded, reducing the study sample to 574.

The diagnoses reported in the medical files were classified into 4 categories, ${ }^{10}$ namely:

1). Trauma

2). Inflammation

3). Degenerative disorders

4). Other ocular modifications

A fifth category was added in this study:

5). No ophthalmologic diagnosis, representing patients with no ocular disturbances and return visits

The definition used in this survey and applied to diagnosis analysis was based on what the ideal client for a new tertiary service would be. ${ }^{7}$ The cases considered to require tertiary ER services were those in need of specialized and immediate care to avoid worsening of the ocular conditions.

The cases considered as requiring primary and secondary care were urgent situations of minor complexity, or nonurgent cases.

Prior to analysis, the information collected from the Ophthalmology ER was recorded into a database. The absolute and relative incidences (as percentages) of the respective diagnoses made during this typical week were then described. The results are presented decriptively on tables and charts.

The survey was approved by the Ethics Committee of the University of São Paulo Medical School General Hospital. As this is an integral part of a doctoral thesis, it was submitted to and approved by the São Paulo State Research Foundation (FAPESP).

\section{RESULTS}

Of the 581 records of patients seen at the Ophthalmology ER from April 01-08, 2006, 574 (98.8\%) were evaluable; 7 records $(1.2 \%)$ were not assessed because the patients left the hospital before the ophthalmologic exam.

Among the 574 files analyzed and classified, inflammation and infection had the highest incidence rate, ie, 316 cases
(55.0\%), followed by trauma, $110(19.2 \%)$; other ocular modifications, 98 (17.1\%); degenerative disorders, 23 (4.0\%); and undiagnosed cases, 27 (4.7\%) (Table 1/ Figure 1) .

Table 1 - Main diagnostic categories of the patients that looked for ophthalmology emergency room of the University of São Paulo Medical School General Hospital

\begin{tabular}{lll} 
& & $\mathrm{n}=574$ \\
\hline Diagnosis & $\mathrm{f}$ & $\%$ \\
\hline inflammation and infection & 316 & 55.0 \\
trauma & 110 & 19.2 \\
degenerative disorders & 23 & 4.0 \\
others oculars modifications & 98 & 17.1 \\
no ophthalmologic diagnostic & 27 & 4.7 \\
Total & 574 & 100.0 \\
\hline
\end{tabular}

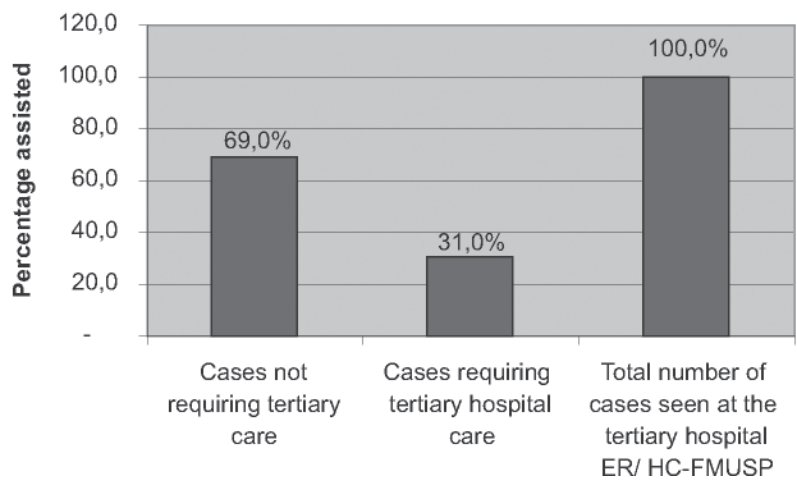

Figure 1 - Cases treated at ER ophthalmolgy of the University of São Paulo Medical School General Hospital requiring/not requiring tertiary care

In the category, inflammation and infection, $\mathrm{n}=316$ $(55.0 \%)$, the cases of conjunctivitis (viral, 140; allergic, 15; sicca syndrome, 10; and bacterial, 4) totaled 169 (29.4\%); eyelid inflammation, 60 (10.5\%); uveitis, 18 (3.1\%); inflamed pterygium, 18 (3.1\%); corneal ulcers; 14 (2.4\%); pingueculitis, 11 (1.9\%); and keratitis, 10 (1.8\%). Other forms of inflammation (episcleritis, 5; herpes, 4; dacryocystitis, 3; orbit cellulitis, 2; blister, 1; optical neuritis, 1) were grouped, due to the small number of cases, totaling $16(2.8 \%)$ (Table 2).

Among the cases of trauma, $\mathrm{n}=110(19.2 \%)$, the most prominent condition was FBC (foreign body on the cornea), 43 (7.5\%); followed by blunt trauma, 30 (5.2\%); burns (thermal and chemical), 14 (2.4\%); corneal abrasion, 10 (1.8\%); and ocular bulb perforation, $5(0.9 \%)$. The remaining cases (conjunctival laceration, 3; corneal abscess, 2; foreign body on the tarsal conjunctiva, 2; and traumatic uveitis, 1) were grouped, due to the small number of cases, totaling $8(1.4 \%)$ (Table 3$)$.

Degenerative disorders, $\mathrm{n}=23(4.0 \%)$ were represented by cataracts, $17(3.0 \%)$; non-acute keratocone, $3(0.5 \%)$; 
Table 2 - Patients with inflammation and infection diagnostics that looked for ophthalmology emergency room of the University of São Paulo Medical School General Hospital

\begin{tabular}{lrcc}
\hline Diagnosis & f & $\begin{array}{c}\% \\
(\mathrm{n}=316)\end{array}$ & $\begin{array}{c}\% \text { from total } \\
(\mathrm{n}=574)\end{array}$ \\
\hline viral conjuctivitis & 140 & 44,30 & 24,4 \\
allergic conjunctivitis & 15 & 4,75 & 2,6 \\
conjunctivitis sicca & 10 & 3,16 & 1,7 \\
bacterial conjunctivitis & 4 & 1,27 & 0,7 \\
meibomitis & 35 & 11,08 & 6,1 \\
hordeolum/ chalazion & 25 & 7,91 & 4,4 \\
uveitis & 18 & 5,70 & 3,1 \\
inflammed pterygium & 18 & 5,70 & 3,1 \\
corneal ulcer & 14 & 4,43 & 2,4 \\
pingueculitis & 11 & 3,48 & 1,9 \\
keratitis & 10 & 3,16 & 1,8 \\
episcleritis & 5 & 1,58 & 0,9 \\
herpes & 4 & 1,27 & 0,7 \\
dacryocystitis & 3 & 0,95 & 0,5 \\
cellulitis & 2 & 0,63 & 0,3 \\
blister & 1 & 0,32 & 0,2 \\
neuritis & 1 & 0,32 & 0,2 \\
Total & 316 & $100,01 \#$ & 55,0 \\
\hline
\end{tabular}

Table 3 - Patients with trauma diagnostics that looked for ophthalmology emergency room of the University of São Paulo Medical School General Hospital

\begin{tabular}{lccc}
\hline Diagnosis & $\mathrm{f}$ & $\begin{array}{c}\% \\
(\mathrm{n}=110)\end{array}$ & $\begin{array}{c}\text { \%of total } \\
(\mathrm{n}=574)\end{array}$ \\
\hline foreign body on the cornea & 43 & 39,1 & 7,5 \\
blunt trauma & 30 & 27,3 & 5,2 \\
corneal abrasion & 10 & 9,1 & 1,8 \\
thermic burn & 8 & 7,3 & 1,4 \\
chemical burn & 6 & 5,5 & 1,0 \\
ocular perforation & 5 & 4,5 & 0,9 \\
laceration of conjunctiva & 3 & 2,7 & 0,5 \\
corneal abscess & 2 & 1,8 & 0,3 \\
foreign body on tarsal conjunctiva & 2 & 1,8 & 0,3 \\
traumatic uveitis & 1 & 0,9 & 0,2 \\
Total & 110 & 100,0 & 19,2 \\
\hline
\end{tabular}

age-related macular degeneration, $1(0.2 \%)$; myopic fundus $1(0.2 \%)$, and bullous keratopathy, $1(0.2 \%)$ (Table 4$)$.

The other ocular modifications category, $\mathrm{n}=98(17.1 \%)$ comprised the remaining cases seen at the Ophthalmologic $\mathrm{ER}$, namely the following: refractive errors, 18 (3.1\%); postoperative, $11(1.9 \%)$; hyposphagma, $10(1.8 \%)$; chronic glaucoma, 10 (1.8\%); detachment of the retina, 8 (1.4\%); trichiasis $5(0.9 \%)$; diabetic retinopathy $5(0.9 \%)$; and strabismus, $5(0.9 \%)$. The remaining diagnoses found (no light perception (NLP)-painful, 3; retinoblastoma, 2; loose spot, 2; epiphora, 2; serous central maculopathy, 2; vitreous hemorrhage, 2; papillary edema, 2; orbital tumor, 1; pseudo tumor, 1 ; ptosis, 1 ; proptosis, 1 ; pannus, 1 ; conjunctival
Table 4 - Diagnostics of patients with degenerative disorders that looked for ophthalmology emergency room of the University of São Paulo Medical School General Hospital

\begin{tabular}{lccc}
\hline Diagnosis & $\mathrm{f}$ & $\begin{array}{c}\% \\
(\mathrm{n}=23)\end{array}$ & $\begin{array}{c}\% \text { of total } \\
(\mathrm{n}=574)\end{array}$ \\
\hline cataracts & 17 & 73,9 & 3,0 \\
keratocone (no acute) & 3 & 13,0 & 0,5 \\
macular degeneration & 1 & 4,3 & 0,2 \\
fundus miopicus & 1 & 4,3 & 0,2 \\
bullous keratopathy & 1 & 4,3 & 0,2 \\
Total & 23 & 100,0 & 4,0 \\
\hline
\end{tabular}

cyst, 1; corneal transplant failure, 1; periocular hematoma, 1 ; hypertensive retinopathy, 1 ; leukemia, 1 ; and under-eye bags, 1). These were grouped due to the small number of cases, $26(4.5 \%)$ (Table 5.)

The true urgent diagnosed cases that requiring complex and immediate treatment in tertiary care units were the following: uveitis, corneal ulcer, episcleritis, herpes , dacryocystitis, orbital cellulitis, neuritis, foreign body on the cornea, blunt trauma, corneal abrasion, burns, ocular perforation, conjunctival laceration, corneal abscess, foreign body on the tarsal conjunctiva, traumatic uveitis, detachment of

Table 5 - Diagnostics of patients with "others oculars modifications" that looked for ophthalmology emergency room of the University of São Paulo Medical School General Hospital

\begin{tabular}{|c|c|c|c|}
\hline Diagnosis & $\mathrm{f}$ & $\begin{array}{c}\% \\
(\mathrm{n}=98)\end{array}$ & $\begin{array}{c}\% \text { of total } \\
(n=574)\end{array}$ \\
\hline refractive errors & 18 & 18,4 & 3,1 \\
\hline postoperative & 11 & 11,2 & 1,9 \\
\hline hyposphagma & 10 & 10,2 & 1,8 \\
\hline chronic glaucoma & 10 & 10,2 & 1,8 \\
\hline detachment of retina & 8 & 8,2 & 1,4 \\
\hline trichiasis & 5 & 5,1 & 0,9 \\
\hline MD retinopathy & 5 & 5,1 & 0,9 \\
\hline strabismus & 5 & 5,1 & 0,9 \\
\hline NLP, painful & 3 & 3,1 & 0,5 \\
\hline retinoblastoma & 2 & 2,0 & 0,3 \\
\hline loose spot & 2 & 2,0 & 0,3 \\
\hline epiphora & 2 & 2,0 & 0,3 \\
\hline central serous maculopathy & 2 & 2,0 & 0,3 \\
\hline vitreous hemorrhage & 2 & 2,0 & 0,3 \\
\hline papillary edema & 2 & 2,0 & 0,3 \\
\hline orbital tumor & 1 & 1,0 & 0,2 \\
\hline pseudotumor & 1 & 1,0 & 0,2 \\
\hline ptosis & 1 & 1,0 & 0,2 \\
\hline proptosis & 1 & 1,0 & 0,2 \\
\hline pannus & 1 & 1,0 & 0,2 \\
\hline conjunctival cyst & 1 & 1,0 & 0,2 \\
\hline corneal failure & 1 & 1,0 & 0,2 \\
\hline periocular hematoma & 1 & 1,0 & 0,2 \\
\hline hypertensive retinopathy & 1 & 1,0 & 0,2 \\
\hline leukemia & 1 & 1,0 & 0,2 \\
\hline under-eye bags & 1 & 1,0 & 0,2 \\
\hline Total & 98 & 100,0 & 17,1 \\
\hline
\end{tabular}


retina NLP-painful, retinoblastoma loose spot, vitreous hemorrhage, papillary edema, orbital tumor, and pseudotumor, $\mathrm{n}=178$ (31.0\%) (Table 6).

The cases that could have been diagnosed and treated in primary or secondary care, ie, not urgent or urgent cases of minor complexity, comprised $69.0 \%$ of all the cases (Chart 1).

In the category "no ophthalmologic diagnosis", $\mathrm{n}=27$ $(4.7 \%)$, patients without ocular disorders were $21(3.6 \%)$, and those on return visits were $6(1.1 \%)$.

Table 6 - Diagnosed urgent cases requiring treatment in tertiary care units - patients that looked for ophthalmology emergency room of the University of São Paulo Medical School General Hospital

\begin{tabular}{|c|c|c|}
\hline Diagnosis & $\mathrm{f}$ & $\%$ \\
\hline uveitis & 18 & 3,1 \\
\hline corneal ulcer & 14 & 2,4 \\
\hline episcleritis & 5 & 0,9 \\
\hline herpes & 4 & 0,7 \\
\hline dacryocistitis & 3 & 0,5 \\
\hline cellulitis & 2 & 0,3 \\
\hline neuritis & 1 & 0,2 \\
\hline foreign body on the cornea & 43 & 7,5 \\
\hline blunt trauma & 30 & 5,2 \\
\hline corneal abrasion & 10 & 1,8 \\
\hline thermic burn & 8 & 1,4 \\
\hline chemical burn & 6 & 1,0 \\
\hline ocular bulb perforation & 5 & 0,9 \\
\hline laceration of the conjunctiva & 3 & 0,5 \\
\hline corneal abscess & 2 & 0,3 \\
\hline foreign body on the tarsal conjuctiva & 2 & 0,3 \\
\hline traumatic uveitis & 1 & 0,2 \\
\hline detachment of the retina & 8 & 1,4 \\
\hline NLP, painful & 3 & 0,5 \\
\hline retinoblastoma & 2 & 0,3 \\
\hline loose spot & 2 & 0,3 \\
\hline vitreous hemorrhage & 2 & 0,3 \\
\hline papillary edema & 2 & 0,3 \\
\hline orbital tumor & 1 & 0,2 \\
\hline pseudotumor & 1 & 0,2 \\
\hline Total & 178 & 31,0 \\
\hline
\end{tabular}

\section{DISCUSSION}

The basic purpose of an Emergency Room is to provide assistance to patients with conditions that might be aggravated by a delay in attention. Therefore, we assume that patients coming to the ER would be those with acute conditions requiring quick intervention for which a delay in attention could lead to organ failure, irreversible damage, and/ or death. This is only possible in society in which the people have the capacity to discern the conditions that need ER and that have access to the Basic Healthcare Unit (UBS).

Quite often, however, there is a conflict between the expectations of the staff working at emergency rooms and the patients' perceptions. In this study, 21 (3.6\%) patients, although they found it necessary to seek an ophthalmologic ER, did not have ocular disorders.

According to Giglio-Jacquemo11 the lay public does not share the same technological and biomedical concept of urgency as do the professional staff. He says, "The patient's illness is not the doctor's illness; between the two there is an important distortion: the first one concerns the individual experience of the disease, the subject's perception of a disturbance, the feeling of something abnormal (pain, suffering, malaise), whereas the second refers to the organic and functional conditions and reports an objectively proven change in the body status." "11 This is one of the reasons for the overcrowded ERs, with the consequent lack of human and material resources, and an imbalance between demand for, and supply of emergency medical care.

It should also be noted that some units are more crowded than others, because they are in well-known hospitals, remain open round the clock, incorporate relevant technology, and have appropriate and specialized medical and nursing staff. This is the case of the ER of University of São Paulo Medical School General Hospital, a large tertiary university hospital, with significant technology incorporation. In São Paulo, it is the reference hospital for people living in central, western and southern areas of the city (according to the public policy for ER care by zone), receiving patients who come spontaneously to the hospital or have been referred to it by other units. This second alternative, however, represents only $5.0 \%$ of the total number of cases, whereas $95.0 \%$ seek medical care at the hospital spontaneously. ${ }^{3}$

In 2005, the Ophthalmology ER at the University of São Paulo Medical School General Hospital received 28,585 patients, $13.6 \%$ of the total number of cases seen at the Emergency Room. ${ }^{8}$

The present survey assessed a typical week (no holiday, strike or half-day holiday that might decrease the usual demand) during which 581 patients were seen. From these, $7(1.2 \%)$ did not wait for their turn and left the hospital before seeing the doctor, reducing the sample to 574. Although the study did not address the reasons why these patients left the hospital, it seems safe to assume they had no severe conditions, or else they would in all likelihood have stayed in the hospital and waited for the ophthalmologic consultation.

The Ophthalmology ER has a permanent staff consisting of 1 medical doctor, assisted by 2 resident physicians on regular week days and 1 resident physician on weekends; 1 senior nurse, responsible for the ER; and 1 nursing assistant. ${ }^{12}$ There are 2 examination rooms with ophthalmologic equipment, 3 slit lamps, drug supplies, Snel- 
len table, direct and indirect ophthalmoscope, ecographic equipment, and access to all the hospital's facilities. Also available is an ophthalmologic surgery room, with a $24-$ hour anesthesiology service.

This is a highly complex and costly structure, prepared for cases that cannot be managed in the more simple units, such as the diagnoses registered in our research that are listed on Table 6, including uveitis (3.1\%), corneal ulcer (2.4\%), episcleritis $(0.9 \%)$, cellulitis $(0.3 \%)$, and others.

In this study, we observed that, despite this complete and expensive structure, $55.0 \%$ of the patients seen at the ER of our Institution had an inflammatory ophthalmologic condition, comprising $29.4 \%$ conjunctivitis and $10.5 \%$ eyelid inflammation (meibomitis, blepharitis, chalazion and hordeolum), cases that could have been treated at low complexity units.

An emergency is defined as a "life-threatening disease process, requiring diagnosis and management within the first few hours after onset" and an "urgency" is defined as an "acute, medical or surgical process, without immediate risk of death, but with risk of a more severe or even fatal outcome." ${ }^{13}$ Considering that "life", in the case of ophthalmology, means the eye's health status in every aspect, including its function, we realize that conjunctivitis and eyelid inflammation are conditions that may well be treated in primary or secondary care units. Additional types of conditions that could be treated in capable institutions that address urgencies of minor complexity and UBS seen at the Ophthalmology ER of our Institution include uncorrected refractive errors, $(3.1 \%)$; postoperative, $(1.9 \%)$; non-acute keratoconus, $(0.5 \%)$; hyposphagma, $(1.8 \%)$; and low vision due to cataracts $(3.0 \%)$.

It should be noted that that some acute processes need urgent tertiary treatment, such as acute glaucoma; acute keratoconus, and others, but they were not found in this study.

Therefore, $69.0 \%$ of the cases seen at the Ophthalmology EC of our Institution could have been diagnosed and treated in primary and/or secondary care units, provided these units perform their tasks appropriately

A study conducted by Mendes \& Caldas Júnior ${ }^{14}$ in 2001 showed that healthcare units in the city of Botucatu supply spontaneous demand for services in a disarticulate and discontinuous fashion, with poor hierarchical structuring, which leaves to the high complexity services the burden of compensating for the deficiency in human and material resources of other units.

Layaun et al, 1992, ${ }^{15}$ assessing the profile of demand for services at the ER of a university hospital, concluded that the public healthcare network, incapable of supplying the necessary human and material conditions to face the demand, eventually refers the patients to 24-hour clinics.

Kara et al, $2001,{ }^{16}$ concluded that $87.5 \%$ of the patients seen at the Ophthalmologic ER of the Campinas University Medical School General Hospital could have had their problem solved in secondary care units. They also point out that $66.7 \%$ of the truly urgent cases and $60.0 \%$ of the falsely urgent cases took more than 7 days to reach the ER, suggesting a poorly structured secondary care system, not only concerning urgencies but also with respect to the orientation given to the patients and to the lack of appropriate means of transportation.

Edwards in $1987^{10}$ found that $71.3 \%$ of the cases seen at an Ophthalmologic ER were conjunctivitis and eyelid inflammation, ie, nonurgent cases, and suggested that nonophthalmologists, could have treated $69.0 \%$ of these patients.

Mendes in $2003,{ }^{17}$ investigating the demand for urgency/ emergency care at a university hospital, found a high percentage of patients with conditions that could have been managed at UBSs and/or secondary care units, and identified deficiencies in the basic level of attention and distortions in local and regional healthcare systems, ultimately leading to a counter-current movement of demand with respect to the hierarchy of the levels of attention.

It becomes clear, therefore, that the problems found in emergency units are no recent issue, nor are they limited to Brazil; such problems have not yet been solved and create unnecessary costs for the State and difficulties for the patients, who should be treated in an expeditious way in units closer to their area of residence.

From the $31.0 \%$ of cases representing actual urgencies, $19.2 \%$ involved trauma; from these, $7.5 \%$ were foreign body on the cornea; $5.2 \%$, blunt trauma, and $0.9 \%$ ocular perforation. It is currently believed that $90.0 \%$ of the cases of ocular trauma may be avoided, with appropriate education and preventive measures. ${ }^{15,17}$.

In this study, we observed that $1.1 \%$ of the cases were return visits. It should be noted that complex cases, such as the corneal ulcers cases, corneal abrasion, and foreign body on the cornea, treated at the ER need to be followed up, and normally the most practical and only possible way is to return to ER. This finding highlights the absence of referral services. How does one send this patient back to the Brazilian Public Healthcare System? Where should he/ she be referred to? Certainly, the lack of appropriate units for referral cause the ER to have to provide this kind of service.

If the Ophthalmology ER of our Institution only received the actually urgent cases (comprising $31.0 \%$ in the present study), and the primary and secondary care units were able to perform their corresponding tasks, there 
would be no unnecessary costs, long lines, lack of human and material resources, and imbalance between supply and demand. The patients, in turn, would have no unnecessary displacement costs; delays in receiving attention, or risk of worsening their prognosis.

\section{CONCLUSIONS}

1). Most patients seen at the Ophthalmology ER of HCFMUSP could be treated in primary or secondary care units.

2 ). An inadequate primary and secondary care system results in unnecessary costs at the tertiary level, in- creased transportation expenses, and wasted time, resulting in physical, emotional, and financial losses by the patients.

\section{SUGGESTIONS}

1). Make improvements in primary and secondary care services so they can treat patients with ophthalmologic disorders of minor complexity.

2). Continuously train and recycle physicians who work at the primary and secondary levels of attention, avoiding unnecessary referrals to high-complexity ERs.

\section{RESUMO}

Carvalho RS, Kara José N. Pronto-Socorro de Oftalmologia do Hospital das Clinicas da Universidade de São Paulo: um hospital terciário para atendimento de nível primário e secundário. Clinics. 2007;62(3):301-8.

OBJETIVO: Verificar a necessidade de atendimento em hospital terciário de casos emergenciais do Pronto-Socorro de Oftalmologia do Hospital das Clinicas da Faculdade de Medicina da Universidade de São Paulo.

MATERIAL E MÉTODO: Realizou-se um estudo transversal analítico em amostra prontamente acessível, $n=574$, de pacientes emergenciais atendidos no Pronto-Socorro Oftalmológico do Hospital das Clínicas da Faculdade de Medicina da Universidade de São Paulo, obtida em semana típica de atendimento.

RESULTADOS: Dos 574 pacientes atendidos, 69,0\% dos casos foram diagnosticados como de simples resolução. Os diagnósticos mais freqüentes estavam relacionados com inflamações e infecções oculares $(55,0 \%)$, entre elas destacaram-se as conjuntivites $(29,4 \%)$ e as inflamações palpebrais (10,5\%). A seguir vêm os traumatismos oculares $(19,2 \%)$, destacando-se os corpos estranhos de córnea $(7,5 \%)$ e trauma contuso $(5,2 \%)$. Os erros de refração $(3,1 \%)$ foram preponderantes na categoria de diagnóstico "outras alterações oculares".

CONCLUSÃO: A maioria $(69,0 \%)$ dos casos atendidos no Pronto-Socorro de Oftalmologia do Hospital das Clínicas da Faculdade de Medicina da Universidade de São Paulo poderia ser diagnosticada e tratada em níveis primário e secundário de atendimento. A procura por um hospital terciário para tratamentos de casos simples, evidencia desestruturação na rede do Sistema Público Brasileiro de Atendimento à Saúde e sobrecarrega uma unidade terciária, cujo custo envolvendo recursos humanos, materiais e de consumo é muito maior.

UNITERMOS: Pronto-socorro. Emergência. Atendimento oftalmológico. Sistema Único de Saúde. Níveis de atendimento. 


\section{REFERENCES}

1. Natalini G. Princípios básicos do SUS", em SUS- o que você precisa saber sobre o Sistema Único de Saúde. Associação Paulista de Medicina, Ed Raiz, São Paulo. volume II, 2001. p. 21-58.

2. Santos JS. Da fundação e Hospital das Clínicas à criação da unidade de emergência e sua transformação em Modelo Nacional de Atenção às Urgências. Medicina,Ribeirão Preto. 2002;35:403-18.

3. Barakat SC. Caracterização da demanda do Serviço de Emergências Clínicas de um hospital terciário do município de São Paulo. PhD thesis, presented to the Internal Medicine Department of the University of São Paulo Medical School; 2004.

4. Santos JS, Scarpelini S, Brasileiro SL, Ferraz CA, Dallora MV, Sá MS. Avaliação do modelo de organização da unidade de emergência do HCFMRP-USP, adotando, como referência, as Políticas Nacionais de Atenção às Urgências e de Humanização. Medicina, Ribeirão Preto, 2003;36:498-515.

5. Portaria ${ }^{\circ}$ 1863/GM Em 29 de setembro de 2003, Ministério da Saúde, http://dtr2001.saude.gov.br/samu/legislacao/leg_gm1863.htm. 19/07/ 2006

6. Ministério da Saúde; Portal: "Sus de A a Z" http://dtr2004.saude.gov.br/ susdeaz/ 15/10/06

7. Cohen A, Elias PE. Saúde no Brasil- Políticas e Organização de Serviços. Ed Cortez, 5a Edição, CEDEC, São Paulo; 2003: p. 60-119.

8. HC, http://www.hcnet.usp.br/informacoes_uteis/conhecendo_hc.htm
9. HC, CoBi / Pareceres . www.henet.usp.br/adm/dc/cobi/consultas.htm

10. Edwards RS. Ophthalmic emergencies in a district general hospital casualty department. Br J Ophthalmol. 1987;71:938-42.

11. Giglio-Jacquemot A. Urgências e Emergências em Saúde: perspectivas de profissionais e usuários. Ed FioCruz, RJ. 2005:13-40.

12. Paim JS. Organização de atenção à saúde para urgência / emergência em Silva,L. M. V. (Org) Saúde coletiva:textos didáticos. Salvador: Centro Editorial e didático/Universidade Federal da Bahia, 1994:p. 152-5.

13. Mendes HB, Caldas Jr AL. "Prática profissional e ética no contexto das políticas de saúde"; Ver Latino-AM Enfermagem. 2001;9:20-6.

14. Layaun SD, Schor P, Rodrigues MV. Perfil da demanda de um serviço de oftalmologia em uma Unidade de Emergência”; Rer Bras De Oftalmol. 1992;51:47-9.

15. Kara Jr N, Zanatto MC, Villaça VN;Nagamati LT, Kara-José N: Aspectos médicos e sociais no atendimento oftalmológico de urgência. Arq Brás Oftalmol. 2001;64:39-43.

16. Mendes HB. Regionalização da assistência à saúde: análise de demanda ao Serviço de Urgência/ Emergência de um hospital universitário. tese para obtenção do grau de Doutor, apresentada na Universidade de São Paulo, Faculdade de Saúde Pública; Departamento de Prática em Saúde Pública; São Paulo, 2003.

17. Alves MR, Kara-José N, Prado Jr J, Usuba FS, Onclinx TM, Marantes CR. Ferimento perfurante ocular: 400 casos admitidos na Clínica Oftalmológica do Hospital das Clínicas da Faculdade de Medicina da Universidade de São Paulo. Arq Bras Oftalmol. 1995;58:342-5. 